\title{
Growth and behavioral responses to elevated temperatures by juvenile sablefish Anoplopoma fimbria and the interactive role of food availability
}

\author{
Susan M. Sogard*, Bori L. Olla \\ Alaska Fisheries Science Center, National Marine Fisheries Service, Hatfield Marine Science Center, Newport, \\ Oregon 97365, USA
}

\begin{abstract}
Larval and age-0 sablefish Anoplopoma fimbria reside in neustonic waters of the North Pacific during spring and summer. We estimated the potential impacts of elevated surface temperatures on ecological processes of growth, conversion efficiency, and behavior in early juvenile sablefish. Growth experiments tested a wide range of temperatures from 6 to $24^{\circ} \mathrm{C}$, with fish receiving ad libitum or low $\left(3 \%\right.$ body weight $\mathrm{d}^{-1}$ ) rations. With unlimited food, growth increased rapidly as temperature increased to $14^{\circ} \mathrm{C}$, then displayed a more gradual rise to $22^{\circ} \mathrm{C}$. Growth rates at the warmer temperatures were among the highest recorded for teleosts, attaining a maximum of $3.3 \mathrm{~mm} \mathrm{~d}^{-1}$ in length and a specific growth in weight of $11.8 \%$. A similar response to temperature was observed at low rations, although at lower overall growth rates. At $24^{\circ} \mathrm{C}$, there was a severe decline in growth for both ration levels, and few fish survived the $3 \mathrm{wk}$ experiments. Gross growth efficiency, measured at temperatures of 6 to $22^{\circ} \mathrm{C}$, displayed an interactive effect of temperature with ration level consistent with bioenergetic relationship. Conversion peaked at 16 to $20^{\circ} \mathrm{C}$ for fish receiving ad libitum rations, and at $10^{\circ} \mathrm{C}$ for fish on restricted rations. Conversion rates of sablefish were comparable to those calculated for a diverse array of fish species, suggesting that the rapid growth rates are driven by high consumption rather than unusually efficient energy transfer. Experiments analyzing sablefish behavior in thermally stratified water columns demonstrated increasing movement into colder water as ration level decreased, in agreement with an energy conserving strategy. Average monthly temperatures within the major nursery areas of neustonic juveniles (north of $40^{\circ} \mathrm{N}$ ) did not exceed $19^{\circ} \mathrm{C}$ during the last $19 \mathrm{yr}$. These results suggest that juvenile sablefish are capable of tolerating and thriving at increased temperatures, with the critical caveat that sufficient food resources must be available. Thus, impacts on early life stages exerted by El Niño conditions, oceanographic regime shifts, or climate changes induced by current global warming scenarios are likely to be a consequence of indirect effects on circulation and productivity patterns rather than direct effects of warmer temperatures. However, because the upper thermal limit for growth nearly coincides with the upper limit for survival, exhibiting a sharp demarcation between favorable growth conditions and intolerable temperatures, juvenile sablefish at the southern limit of their distribution may suffer the direct effects of elevated temperature; recruitment of juveniles to southern populations may become more sporadic if the frequency of warming events increases with climate change.
\end{abstract}

KEY WORDS: Growth efficiency · Temperature selection · Ration · Activity

\section{INTRODUCTION}

Temperature plays a broad and decisive role in the ecology of most ectotherms, making them highly sus-

*E-mail: susan.sogard@noaa.gov ceptible to climate patterns that alter their normal temperature regime. In North Pacific ecosystems, such alterations occur regularly on intra-decadal or decadal scales in association with fluctuations in the El NiñoSouthern Oscillation cycle and with oceanographic regime shifts (Francis et al. 1998, Beamish et al. 1999). 
For example, the 1997/1998 El Niño caused temperature anomalies of $>5^{\circ} \mathrm{C}$ above long-term means in some regions of the eastern North Pacific (Smith et al. 1999). In addition to these ongoing cycles, current models of climate change predict a long-term trend of increased temperatures associated with global warming, with mean global surface temperatures expected to increase by 1 to $3.5^{\circ} \mathrm{C}$ by 2100 (Watson et al. 1997). Climate conditions that alter water temperatures also induce a broad suite of other oceanographic changes that can impact fish populations, including shifts in circulation patterns and primary production, and distributional shifts of species communities. For example, a corollary of higher surface temperatures during El Niño conditions in the eastern North Pacific is a reduction of upwelling in coastal waters and a decrease in primary production, with cascading effects throughout the food web (Wooster \& Fluharty 1985, Bakun 1996). Predicting the response of fish populations to oceanographic conditions that increase surface temperatures, therefore, requires understanding of both the direct effects of temperature and the interactive effects of temperature with other changes in the ecosystem. In this study we examine the interactive effects of temperature and food availability on growth and behavior of juvenile sablefish Anoplopoma fimbria, a common resident of North Pacific waters and, due to the neustonic habitat occupied by larval and early juvenile stages, likely to experience the most extreme incidence of elevated water temperatures generated by warming processes in this ecosystem.

Although much prior research has been directed toward determining upper and lower lethal thermal limits for fishes, we believe this approach has limited utility in evaluating the effects of altered temperature regimes on fishes. Rather, it is imperative to establish the sublethal effects of temperature on basic ecological processes such as growth. Thermal mediation of growth rates occurs primarily through behavioral processes that control consumption and physiological processes that control metabolic rates, digestion rates, osmoregulation, ion uptake, and ultimately, survival. A particularly crucial environmental factor that interacts with temperature is the availability of food. As temperature increases, accelerated physiological rates can be supported by increased catabolism, but body mass can be maintained only if food consumption increases to provide the required energy resources. Any restriction on food consumption resulting in rations that are below ad libitum levels will shift the balance of energy allocation between physiological requirements and growth. As a consequence of these interactions, the optimal temperature for growth decreases as food availability decreases (Brett et al. 1969, Crowder \& Magnuson 1983). Gross conversion efficiency, the rate at which food biomass is converted to fish biomass, is generally highest at temperatures slightly below those supporting the fastest growth rates (Brett et al. 1969, Woiwode \& Adelman 1991, Jobling 1996). If bioenergetic costs and benefits affect habitat selection, the behavior of fish should also be influenced by interactive effects of temperature and food availability. In a heterogeneous thermal environment, fish can reduce their metabolic costs by moving into colder temperatures as food availability decreases. Such a response has been experimentally demonstrated in juvenile walleye pollock (Sogard \& Olla 1996) and other species (Stuntz \& Magnuson 1976, Mac 1985, Morgan 1993) and invoked to explain distributional shifts in the field (Rudstam \& Magnuson 1985, Welch et al. 1998).

Because of their habitat and behavior, early life history stages of juvenile sablefish are likely to be exposed to the highest water temperatures associated with climatic fluctuations in the Northeast Pacific. Spawning and incubation of sablefish occur in midwinter in demersal slope waters occupied by adults. Yolk-sac larvae gradually migrate to surface waters as the yolk is absorbed (McFarlane \& Beamish 1992). Larvae and age- 0 juvenile stages reside in neustonic waters throughout the summer, with some migration to demersal habitats in the fall. Off Oregon, juveniles are abundant only at distances $>30 \mathrm{~km}$ from the coast (Shenker 1988). This habitat is offshore of the zone of upwelling influence, with temperatures typically approaching the maximum for this latitude, in contrast to the colder inshore temperatures derived from coastal upwelling.

Age-0 sablefish have been described as obligate neuston residents (Kendall \& Matarese 1987, Doyle et al. 1994), based on their absence in obliquely towed nets. In laboratory experiments using a $2.5 \mathrm{~m}$ tall tank, we have demonstrated a moderate behavioral preference for the surface layer under isothermal conditions and a strong surface preference in a thermally stratified water column (Sogard \& Olla 1998a). Individual fish will, however, move downward into cold water for short periods if food is present in the bottom layer. The tendency to leave the surface layer in either an isothermal or stratified water column increases as fish size increases and as prior foraging success (and thus body condition) decreases. Thus, the dependence of juveniles on the neuston layer may be tempered by environmental conditions and ontogeny.

Growth rates of juvenile sablefish at moderate temperatures $\left(12\right.$ to $\left.13^{\circ} \mathrm{C}\right)$ are notably high, exceeding $2 \mathrm{~mm} \mathrm{~d}^{-1}$ for fish in a size range of 30 to $130 \mathrm{~mm}$ TL (Shenker \& Olla 1986, Sogard \& Olla 2000). Rapid growth rates have also been estimated from otolith analyses of field populations (Boehlert \& Yoklavich 1985). In this study we extend analyses of growth rates 
and conversion efficiency to a broad range of temperatures $\left(6\right.$ to $24^{\circ} \mathrm{C}$ ) and examine the vertical distribution of juveniles maintained on varying rations in a thermally stratified water column. In a prior study we found that sablefish held on ad libitum ration levels exhibited avoidance behavior and a disrupted diel pattern of activity when subjected to very cold temperatures $\left(3^{\circ} \mathrm{C}\right.$, Sogard \& Olla 1998b). Behavioral responses to elevated temperatures have not been previously examined. Our goals were to (1) estimate the maximum temperature allowing positive growth; (2) examine the interactive effects of temperature and food availability on growth; (3) determine the optimal temperature for conversion efficiency and any interactive effects with ration level; and (4) test for a bioenergetic response by exposing fish held on varying ration levels to a stratified water column. For the latter objective we predicted that fish would make increasing use of colder temperatures as food availability declined to low levels.

\section{MATERIALS AND METHODS}

Juvenile sablefish used in laboratory experiments were collected in spring 1997, 1998 and 1999 approximately $40 \mathrm{~km}$ offshore of Newport, Oregon, USA, using neuston nets at night. Prior to experiments, fish were maintained in groups in 4501 holding tanks in a continuously exchanging seawater system at ambient temperatures (mean $=12^{\circ} \mathrm{C}$ ). They were fed daily with an ad libitum ration of 1 to $2 \mathrm{~mm}$ diameter BioDiet pellets.
Growth and activity at varying temperatures. Growth experiments were conducted for $3 \mathrm{wk}$ each at temperatures of $6,10,14,16,18$, and $20^{\circ} \mathrm{C}$ in 1997 and $14,16,18,20,22$, and $24^{\circ} \mathrm{C}$ in 1999 (Table 1). At the beginning of an experiment, pairs of fish were matched for size and randomly assigned to 1741 tanks. Each tank was randomly assigned to either a high (ad libitum) or low (3\% body weight $\mathrm{d}^{-1}$ on a wet weight basis) ration level. There were 6 replicate tanks for each temperature/ration treatment. Because the 2 fish in a tank were closely similar in size and prior experiments have suggested minimal differences in food acquisition even between disparately sized sablefish (Sogard \& Olla 2000), we expected them to have equal access to food. Because of low survival in the initial trial at $24^{\circ} \mathrm{C}$, a second trial was conducted, resulting in 12 replicates of each ration level at that temperature. Data were pooled for both $24^{\circ} \mathrm{C}$ trials for subsequent analyses. The diet consisted of $2 \mathrm{~mm}$ BioDiet pellets, with a composition of $45 \%$ protein, $15 \%$ fat, $8.5 \%$ carbohydrate, and $20.5 \%$ water. The high protein and fat content of the pellets presumably exceeded that available in the natural diet of early juvenile sablefish, which is dominated by copepods and amphipods (Grover \& Olla 1987, J. J. Grover \& S. M. Sogard unpubl. data). Daily rations were delivered with automatic feeders over the course of several hours to maximize food consumption.

During the first week, temperatures were gradually raised or lowered at a rate of $2^{\circ} \mathrm{C} \mathrm{d}^{-1}$ to the test level. Fish were lightly anesthetized with MS-222 and measured at the beginning and end of each week. All mea-

Table 1. Outline of growth and growth efficiency experiments indicating initial mean sizes. $\mathrm{n}=24$ fish for all growth experiments and 12 fish for all efficiency experiments

\begin{tabular}{|c|c|c|c|c|}
\hline Year & Temp $\left({ }^{\circ} \mathrm{C}\right)$ & Start date & Mean total length (TL) (SD) & Mean wet weight (SD) \\
\hline \multicolumn{5}{|c|}{ Growth experiments } \\
\hline 1997 & 6 & May 12 & $51(9.2)$ & $0.76(0.39)$ \\
\hline 1997 & 10 & Jun 2 & $67(10.5)$ & $1.64(0.74)$ \\
\hline 1997 & 14 & May 12 & $50(10.7)$ & $0.76(0.44)$ \\
\hline 1997 & 16 & Jun 2 & $69(9.9)$ & $1.72(0.66)$ \\
\hline 1997 & 18 & May 12 & $51(7.6)$ & $0.75(0.33)$ \\
\hline 1997 & 20 & Jun 2 & $68(10.2)$ & $1.61(0.77)$ \\
\hline 1999 & 14 & Jul 8 & $63(7.4)$ & $1.50(0.57)$ \\
\hline 1999 & 16 & Jul 8 & $62(6.5)$ & $1.45(0.46)$ \\
\hline 1999 & 18 & Jun 16 & $54(10.4)$ & $0.90(0.51)$ \\
\hline 1999 & 20 & Jun 16 & $55(12.4)$ & $1.06(0.81)$ \\
\hline 1999 & 22 & May 25 & $50(9.4)$ & $0.79(0.42)$ \\
\hline 1999 & 24 & May 25 & $50(8.6)$ & $0.75(0.37)$ \\
\hline 1999 & 24 & Aug 2 & $88(5.5)$ & $3.83(0.73)$ \\
\hline \multicolumn{5}{|c|}{ Growth efficiency experiments } \\
\hline 1999 & 6 & Aug 25 & $102(6.2)$ & $6.18(1.21)$ \\
\hline 1999 & 10 & Aug 4 & $84(5.8)$ & $3.78(0.87)$ \\
\hline 1999 & 16 & Jun 2 & $55(4.3)$ & $0.84(0.19)$ \\
\hline 1999 & 20 & Jun 23 & $57(4.5)$ & $1.05(0.22)$ \\
\hline 1999 & 22 & Jul 14 & $64(3.6)$ & $1.56(0.27)$ \\
\hline
\end{tabular}


surements were made prior to feeding for that day. Rations were adjusted each week based on the mean weights at the beginning of the week. Growth was evaluated for the second and third weeks, after target temperatures were attained.

At the conclusion of experiments conducted in 1999, groups were randomly selected for measurement of swimming activity levels. Prior to final length and weight measurements, groups were transferred to circular (122 cm diameter), 3401 tanks filled with water of the same temperature used during growth evaluation. After a 30 min acclimation period, groups were videotaped with overhead cameras. There were 4 replicate groups from each ration/temperature treatment, with the exception of the $24^{\circ} \mathrm{C}$ treatment, which had only 1 tank with survivors in the high ration treatment. Each group was filmed for $1 \mathrm{~h}$; no food was present during filming. Videotapes were analyzed with an image analysis system using a digitizing pen to trace the movement of individual fish. Each fish of a pair was tracked for $30 \mathrm{~s}$, with 4 sets of observations at approximately $10 \mathrm{~min}$ intervals. Due to the shallow water depth $(30 \mathrm{~cm})$, movement occurred primarily in the horizontal plane, justifying use of the overhead 2dimensional video image to assess activity. The average speed of fish (body lengths $\mathrm{s}^{-1}$ ) moving through the tank was calculated for each interval and averaged overall for each group.

Growth efficiency, consumption rates, and allocation. Conversion efficiency was calculated for fish held individually in 821 tanks ( $\mathrm{n}=12$ replicates per temperature) in a flow-through system during $3 \mathrm{wk}$ experiments in 1999 (Table 1). Fish were randomly assigned a low ( $3 \%$ body weight [bw] $\mathrm{d}^{-1}$ on a wet weight basis) or high (ad libitum) ration. Temperatures tested were $6,10,16,20$, and $22^{\circ} \mathrm{C}$. Temperatures were ambient (mean $=12^{\circ} \mathrm{C}$ ) when fish were introduced to tanks, and gradually increased or decreased at a rate of $2^{\circ} \mathrm{C} \mathrm{d}^{-1}$ to the target level during the first week. Fish received either 2 or $3 \mathrm{~mm}$ BioDiet pellets (composition noted above) distributed from automatic feeders over a $1 \mathrm{~h}$ period. Pellets remaining in tanks after the feeding period were counted and removed by siphoning. The total number of pellets consumed each week by each fish was determined and the dry weight of food consumed calculated from previously determined relationships.

At the conclusion of each experiment, fish were weighed and measured, then dried to a constant weight at $50^{\circ} \mathrm{C}$ in a drying oven. The percentage dry weight of each individual was determined. Consumption rate, growth rate, conversion efficiency and body constituent analyses were calculated only for the third week of experiments, after all fish had experienced the target temperature for all of Week 3, all of Week 2, and part of Week 1 (when temperatures were adjusted to their final value). Because the proximate composition of fish appeared to be modified by growth rates (see below), we made the assumption that the percentage dry weight of each individual at the beginning of the final week was comparable to the final determination. The growth increment in dry weight for the final week was determined based on this estimate of initial dry weight. Gross growth efficiency was calculated as dry weight increment/dry weight consumed $\times 100$.

Behavioral responses to thermal stratification. The vertical distribution of juvenile sablefish was examined under 2 varying thermal regimes, using $2.5 \times 2.5 \times$ $2.5 \mathrm{~m}$ tanks with a partition in the middle restricting fish to the front half. Experiments used age-0 fish from the 1998 yr class ranging in size from 232 to $365 \mathrm{~mm}$ TL (69 to $383 \mathrm{~g}$ wet weight). Fish were captured from the field in the spring and held in laboratory tanks on ad libitum rations at ambient temperatures (mean $=12^{\circ} \mathrm{C}$ ) until experiments were conducted in the fall. For an experiment, fish were acclimated to 1 of 4 rations: ad libitum, maintenance (approximately $2 \% \mathrm{bw} \mathrm{d}^{-1}$ ), no food for $30 \mathrm{~d}$, and no food for $60 \mathrm{~d}$. Fish on the ad libitum and maintenance rations were held on these rations for at least $30 \mathrm{~d}$ before an experiment. Thermal regimes included an isothermal water column at $12{ }^{\circ} \mathrm{C}$, a warm stratified column that averaged $19^{\circ} \mathrm{C}$ at the surface and $11^{\circ} \mathrm{C}$ at the bottom, and a cold stratified column that averaged $14^{\circ} \mathrm{C}$ at the surface and $6^{\circ} \mathrm{C}$ at the bottom. We used 2 different stratification regimes to allow distinction between the influence of temperature on behavior and selection for particular depths in the tank. Stratified water columns were created by adding progressively colder water to the bottom of the tank from external thermal reservoirs that could be either heated or cooled to specified temperatures. Water was added to the tank in layers that effectively generated an even thermal gradient from surface to bottom. The isothermal water column was considered a control and was employed only with fish that had received ad libitum rations. There were 5 to 7 replicate groups for each stratification/ration treatment, with a total of 56 groups.

We tested fish in groups of 2 to allow social interactions; age-0 sablefish begin schooling behavior at a size of about $50 \mathrm{~mm}$ (authors' unpubl. data). Pairs of fish were added to the tanks after creation of the specified thermal regime and just before dark. They were allowed to acclimate throughout the night. The following day, each group was videotaped for $2 \mathrm{~h}$ in the morning and $2 \mathrm{~h}$ in the afternoon. Fish were not fed in the experimental tanks. Videotapes were analyzed with an image analysis system in which fish movements were traced with a digitizing pen on a video monitor. At intervals of approximately $30 \mathrm{~min}$, each 
individual of a pair was traced for $30 \mathrm{~s}$, creating a stream of 600 vertical and horizontal position coordinates. From these data, the mean vertical position and mean temperature occupied was determined, based on the temperature profile for that group. In addition, the mean swimming speed (body lengths $\mathrm{s}^{-1}$ ) was calculated, based on the distance covered by each fish during the $30 \mathrm{~s}$ of tracing. Swimming speed was used as an overall index of motor activity levels.

Data analysis. For the growth rate experiments, we calculated individual growth in length to illustrate the range of potential growth among the various temperature and ration treatments. For statistical comparisons, specific growth in weight $\left\{\left[\log _{\mathrm{e}}\right.\right.$ (final weight) $-\log _{\mathrm{e}}(\mathrm{ini}-$ tial weight)] $/ d \times 100\}$ was calculated for each individual for each week of an experiment, and the mean of the 2 individuals in a tank used in analyses. Minimal differences in growth for the same temperature in 2 different years (1997 and 1999) were evident so the 2 years were combined. Because specific growth rates declined with fish size, the effects of temperature and ration were compared using 2-way ANCOVAs, with initial mean weight as a covariate. Analyses were conducted separately for each week of the experiments. Activity levels of fish in 1999 growth experiments, indexed by swimming speeds, were analyzed for temperature and ration effects with 2-way ANOVA. For the conversion efficiency experiment, interactive effects of temperature and ration on growth and efficiency for the third week were assessed using 2-way ANOVA. For the behavior experiment, mean temperatures occupied by sablefish and their activity levels were tested for effects of stratification regime and ration using 2-way ANOVA. Post-hoc Tukey tests $(\alpha=$ 0.05 ) were used to evaluate significant pairwise differences following ANOVA tests.

\section{RESULTS}

\section{Growth and activity at varying rations and temperatures}

Temperature and ration exerted clear effects on growth rates of juvenile sablefish. Daily growth in length varied from -0.3 to $3.3 \mathrm{~mm} \mathrm{~d}^{-1}$ for fish receiving high rations and from -0.3 to $1.4 \mathrm{~mm} \mathrm{~d}^{-1}$ for fish receiving low rations (Fig. 1). For wet weight, specific growth rates ranged from -1.0 to $11.8 \%$ for fish on high rations and from -2.6 to $6.5 \%$ for fish on low rations. The general pattern exhibited by fish on high rations was a rapid increase in growth rate from 6 to $14^{\circ} \mathrm{C}$, a more gradual rise approximating a plateau from 14 to $22^{\circ} \mathrm{C}$, and a sharp decline at $24^{\circ} \mathrm{C}$ (Fig. 2). For fish held on low rations, there was an increase in growth rate at

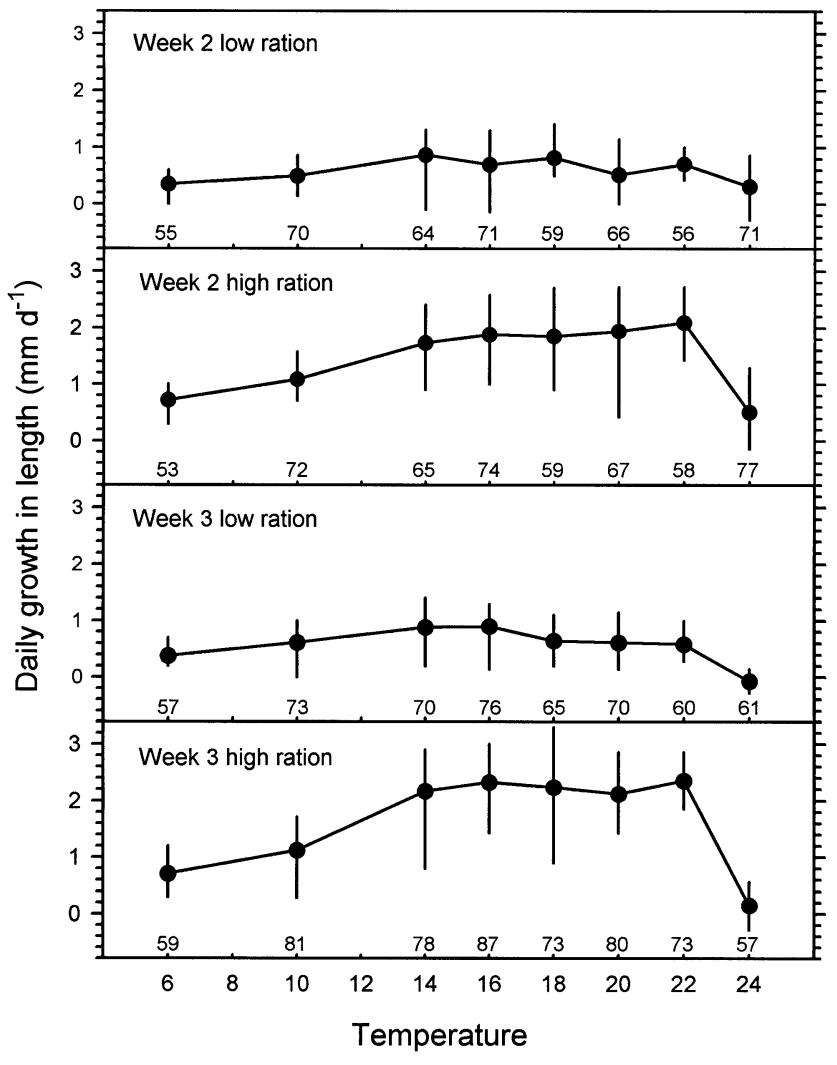

Fig. 1. Mean ( \pm range) of daily growth in length for juvenile sablefish held on high or low rations at temperatures from 6 to $24^{\circ} \mathrm{C}$ during Weeks 2 and 3 of the growth experiments. Values below each data point are the mean total lengths of fish in each treatment at the beginning of each week

warmer temperatures, but the degree of contrast between different temperatures was more moderate. As a consequence there was a significant interaction between temperature and ration effects for both weeks analyzed (ANCOVA, Table 2). Post-hoc Tukey tests comparing growth rates within the high ration groups demonstrated clear differences between the middle range of temperatures and the endpoints of $\leq 10$ or $24^{\circ} \mathrm{C}$. Within the range of 14 to $22^{\circ} \mathrm{C}$, the fastest growth rate was at $22^{\circ} \mathrm{C}$ in both weeks, but there were few significant differences among the 5 mid-range temperatures (Fig. 2). For fish held on low rations, in Week 2 the fastest growth was at $14^{\circ} \mathrm{C}$, but did not differ significantly among temperatures from 14 to $24^{\circ} \mathrm{C}$. In Week 3, growth rates of low ration groups were similar from 10 to $22^{\circ} \mathrm{C}$ and significantly higher than at 6 or $24^{\circ} \mathrm{C}$. Growth rates at $24^{\circ} \mathrm{C}$ were positive in Week 2 for both ration levels, but decreased to negative values in Week 3.

Swimming activity rates measured at temperatures of 14 to $24^{\circ} \mathrm{C}$ in conjunction with growth experiments in 1999 displayed a gradual increase as temperature 

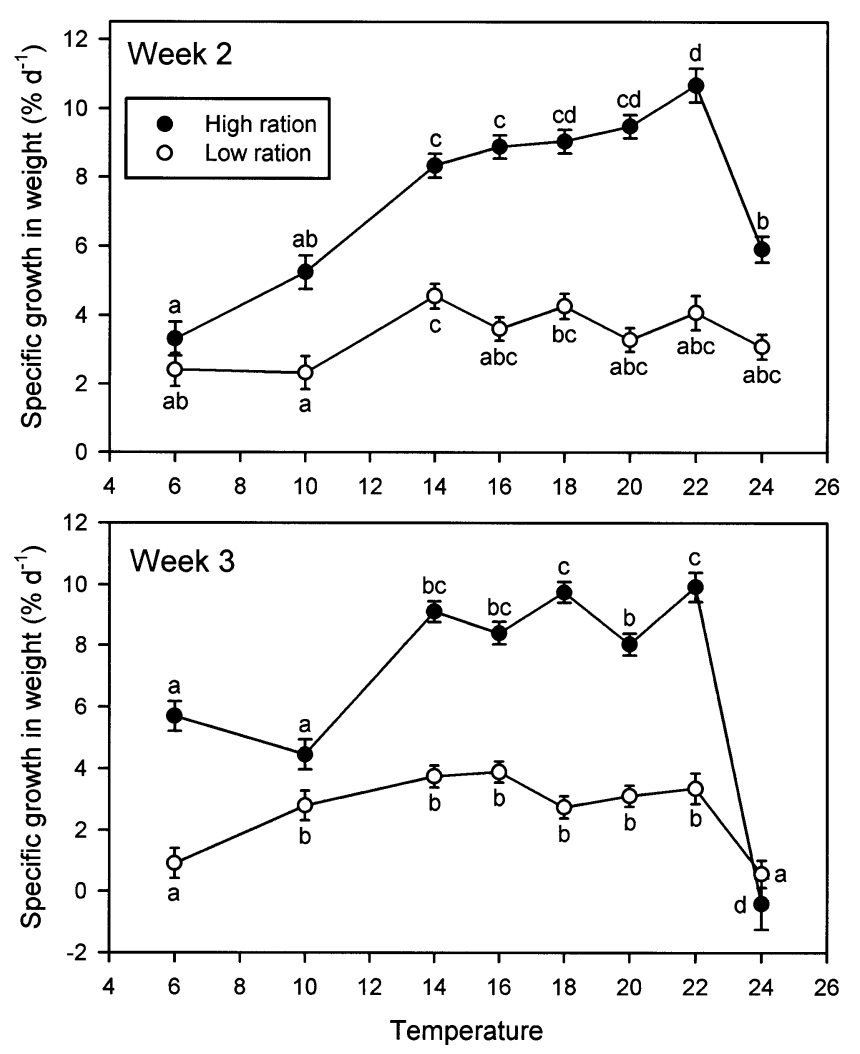

Fig. 2. Mean ( $\pm \mathrm{SE})$ specific growth in weight for juvenile sablefish held on high or low rations at temperatures from 6 to $24^{\circ} \mathrm{C}$ during Weeks 2 and 3 of the growth experiments. Plotted values are least-squares means adjusted for initial weight at the beginning of each week. Growth rates of the 2 individuals in a tank were averaged prior to analysis. Values with the same letter were not significantly different from others within a ration level based on post-hoc Tukey tests $(\alpha=0.05)$ at temperatures $<24^{\circ} \mathrm{C}$. The few mortalities were either fish that were very small at the beginning of an experiment and died within the first week or fish that jumped out of tanks; there was no evidence of cannibalism. The 2 trials testing growth at $24^{\circ} \mathrm{C}$ used different sizes of fish (mean TL $=50 \mathrm{~mm}$ in the first trial and $89 \mathrm{~mm}$ in the second trial) and had different survival rates, with $50 \%$ for the smaller fish and $4 \%$ for the larger fish (only 1 fish out of 24 survived the $3 \mathrm{wk}$ trial). All of the fish in the two $24^{\circ} \mathrm{C}$ trials, whether they survived or not, exhibited similar external symptoms of stress-induced trauma, including hemorrhaging fins, swelling throughout the torso in the region just posterior to the anus, and deformation of the vertebral column. These symptoms were not observed in any of the fish held at other temperatures.

\section{Growth efficiency, consumption rates, and allocation}

Consumption rates for fish receiving ad libitum rations generally followed the expected parabolic pattern, increasing as temperature increased to $20^{\circ} \mathrm{C}$, then declining at the highest temperature tested $\left(22^{\circ} \mathrm{C}\right.$, Fig. 3). Two individuals, however, exhibited extremely high consumption rates at $22^{\circ} \mathrm{C}$. These 2 fish were similar in size and had similar growth rates compared with other individuals in this treatment, but much lower growth efficiencies. At the coldest temperature $\left(6^{\circ} \mathrm{C}\right)$, fish on ad libitum rations did not consume more food than fish held on low rations.

Growth rates during Week 3 of the efficiency experiment (Fig. 4) were generally comparable to those increased from 14 to $22^{\circ} \mathrm{C}$, but declined to near zero at $24^{\circ} \mathrm{C}$ (Table 3 ). Fish at the latter temperature typically remained motionless on the bottom of the filming tanks throughout all trials. Because of the lack of variance in the $24^{\circ} \mathrm{C}$ groups, statistical comparisons were conducted only on groups at 14 to $22^{\circ} \mathrm{C}$. Temperature had a significant effect on activity $\left(F_{4,30}=6.05, \mathrm{p}=\right.$ $0.001)$, but ration did not $\left(F_{1,30}=0.68\right.$, $\mathrm{p}=0.417$; temperature $\times$ ration interaction $F_{4,30}=0.59, \mathrm{p}=0.670$ ). Based on post-hoc Tukey tests, swimming speeds were significantly lower at 14 and $16^{\circ} \mathrm{C}$ than at $22^{\circ} \mathrm{C}$, but there were no other significant differences.

Survival of fish in the growth experiments ranged from 88 to $100 \%$ for fish
Table 2. Results of 2-way ANCOVAs comparing specific growth rates on high and low rations at varying temperatures in Weeks 2 and 3 (after target temperatures were achieved) of growth experiments with juvenile sablefish. Replicates were the mean growth for each tank, with 2 fish tank ${ }^{-1}$. The mean weight of each tank pair at the beginning of each week was included as a covariate. Total df differed between Weeks 2 and 3 due to mortality, primarily of the $24^{\circ} \mathrm{C}$ groups

\begin{tabular}{|lrrrr|}
\hline Factor & df & MS & \multicolumn{1}{c|}{$F$} & $\mathrm{p}$ \\
\hline Week 2 & & & & \\
Temperature & 7 & 36.47 & 25.81 & $<0.001$ \\
Ration & 1 & 579.99 & 410.58 & $<0.001$ \\
Temp $\times$ Ration & 7 & 14.04 & 9.94 & $<0.001$ \\
Initial weight & 1 & 93.23 & 65.70 & $<0.001$ \\
Error & 136 & 1.41 & & \\
Week 3 & & & & $<0.001$ \\
Temperature & 7 & 46.28 & 33.35 & $<0.001$ \\
Ration & 1 & 436.41 & 314.51 & 0.001 \\
Temp $\times$ Ration & 7 & 17.17 & 12.38 & \\
Initial weight & 1 & 15.26 & 11.00 & \\
Error & 122 & 1.39 & & \\
\hline
\end{tabular}


Table 3. Mean ( \pm SE) swimming speed in body lengths $\mathrm{s}^{-1}$ for sablefish observed at the conclusion of the 1999 growth experiment. Fish were held on high or low rations for $3 \mathrm{wk}$ prior to observations

\begin{tabular}{|c|c|c|c|c|c|c|}
\hline \multirow[t]{2}{*}{ Ration } & \multicolumn{6}{|c|}{ Temperature $\left({ }^{\circ} \mathrm{C}\right)$} \\
\hline & 14 & 16 & 18 & 20 & 22 & 24 \\
\hline High & $1.79(0.15)$ & $1.58(0.23)$ & $2.34(0.11)$ & $2.43(0.34)$ & $2.34(0.20)$ & $0.0(0.0)$ \\
\hline Low & $1.73(0.19)$ & $1.97(0.17)$ & $2.26(0.23)$ & $2.18(0.09)$ & $2.51(0.13)$ & $0.05(0.05)$ \\
\hline
\end{tabular}

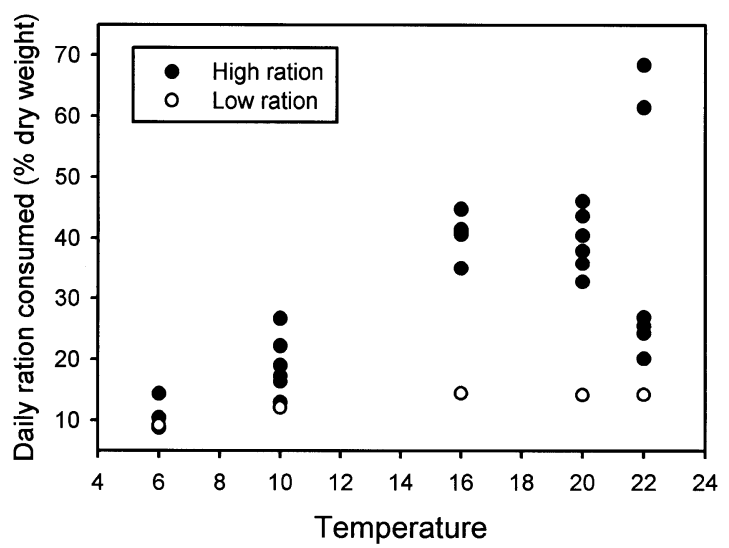

Fig. 3. Consumption rates calculated on a dry weight basis during Week 3 for juvenile sablefish in the conversion efficiency experiment. Fish were held on high or low rations at temperatures from 6 to $22^{\circ} \mathrm{C}$. Low ration values are means; standard errors are not detectable since most fish consumed all the available ration, resulting in minimal variation. High ration values represent individual fish

observed in the growth experiments (Fig. 2), except for high ration groups at $22^{\circ} \mathrm{C}$. In this experiment growth significantly declined as temperature increased from 20 to $22^{\circ} \mathrm{C}$.

The efficiency with which dry biomass of food was converted to dry biomass of sablefish was highly variable at 6 and $22^{\circ} \mathrm{C}$ but more consistent at intermediate temperatures (Fig. 4). There was a clear interaction in the influence of temperature and ration on conversion efficiency (2-way ANOVA, $F_{4,43}$ for temperature $\times$ ration interaction $=5.71, p<0.001)$. For both ration levels, efficiency declined at either extreme of the temperatures tested. For fish on high rations at $22^{\circ} \mathrm{C}$, efficiencies were low including $(18.1 \%)$ or excluding $(23.2 \%)$ the 2 fish that had extremely high consumption rates. The temperature supporting the highest efficiency differed depending on ration. At low rations, the highest efficiency was at $10^{\circ} \mathrm{C}$, whereas at high rations, the highest efficiency was at the warmer temperatures of 16 to $20^{\circ} \mathrm{C}$. Comparison of ration levels within each temperature demonstrated significantly higher efficiency at high rations for temperatures of 16 and $20^{\circ} \mathrm{C}$, but no difference between rations at the other temperatures (post-hoc Tukey tests, $\alpha=0.05$ ).
Sablefish differed in their pattern of allocation of energy to biomass depending on their foraging success and absolute growth rate. Regardless of temperature, fish that were growing rapidly had a higher percentage dry weight at the conclusion of experiments (Fig. 5). Growth during Week 3 was highly correlated with final percentage dry weight, whereas temperature had no effect (ANCOVA; for temperature, $F_{4,47}=$
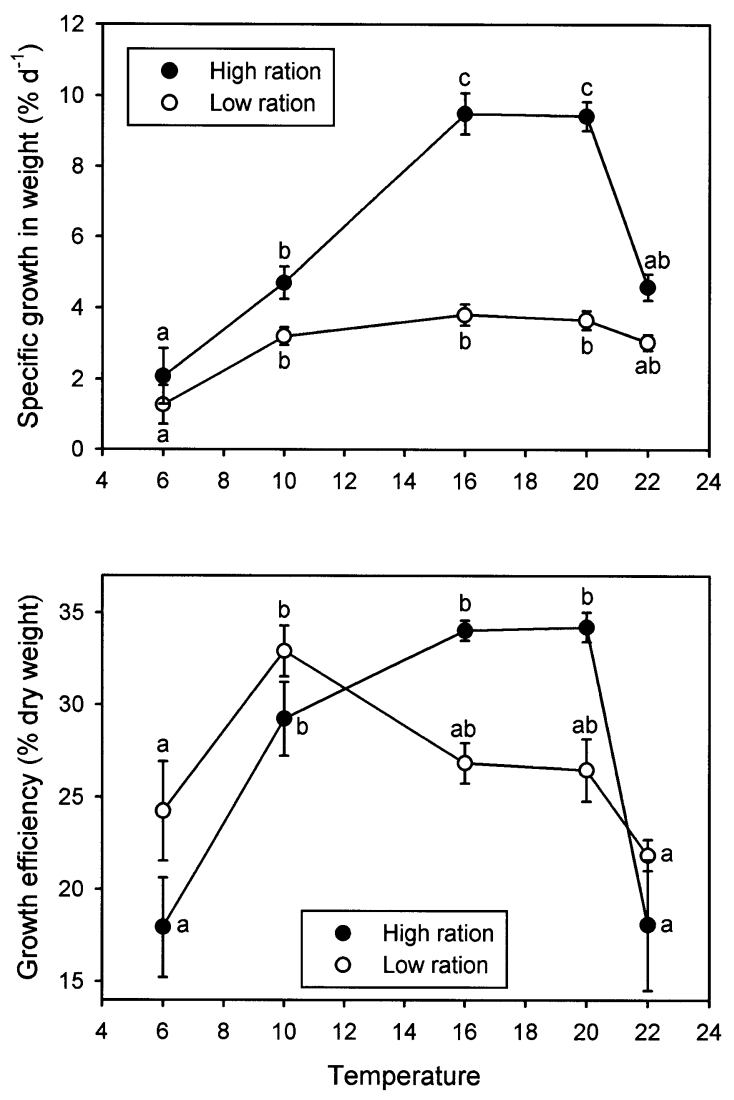

Fig. 4. Mean ( \pm SE) specific growth in weight (upper graph) and conversion efficiency calculated on a dry weight basis (lower graph) for juvenile sablefish held on high or low rations at temperatures from 6 to $22^{\circ} \mathrm{C}$ during Week 3 of the efficiency experiments. Growth values are least-squares means adjusted for initial weight at the beginning of Week 3; efficiency values are unadjusted means. Values with the same letter were not significantly different from others within a ration level based on post-hoc Tukey tests $(\alpha=0.05)$ 


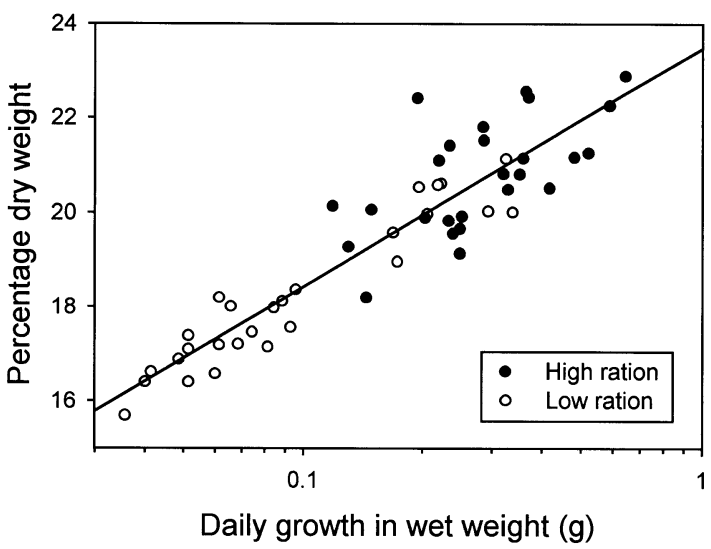

Fig. 5. Relationship of final percentage dry weight vs absolute growth rate during Week 3 for all individual sablefish in the efficiency experiments. Fish were held on high or low rations, with dry weight determined at the conclusion of $3 \mathrm{wk}$ trials. Note $\log _{10}$ scale for growth rate

1.61, $\mathrm{p}=0.187$; for $\log _{10}$ growth in Week $3, F_{1,47}=$ $237.13, \mathrm{p}<0.001)$. Although absolute growth rate is a complex function of initial fish size, temperature, and ration consumed, these other variables were not as highly correlated with the percentage of dry weight.

\section{Behavioral responses to thermal stratification}

Age-0 sablefish moved throughout the experimental tank under isothermal conditions at $12^{\circ} \mathrm{C}$ (Fig. 6). The 2 fish in a pair typically oriented toward one another and followed one another in their movements through the tank. The influence of thermal stratification on vertical distribution depended on the range of temperatures provided and ration level. At high rations, sablefish in a warm stratified system also moved throughout the water column, but spent most ( $76 \%$ ) of the time at mid-depths, whereas sablefish in a cold stratified system avoided the colder depths and occurred primarily $(89 \%)$ in the warmer upper half of the tank.

Food deprivation resulted in a clear shift in vertical distribution to colder temperatures for both stratifica- tion treatments. At the lowest ration level, sablefish spent $82 \%$ of their time in the bottom layer under warm stratification and $69 \%$ under cold stratification. Time spent in the bottom layer was partly a consequence of a sharp increase in the time spent resting on the bottom of the tank as food levels declined (Table 4). To distinguish further between occurrence in colder temperatures as a consequence of passive resting behavior and active temperature selection, we analyzed only those observations in which fish were off the bottom of the tank and actively moving. Within this more restricted data set, a decline in the average temperature occupied by sablefish as ration declined was still evident (Fig. 7). Statistical comparisons indicated significant effects of ration and stratification type on the mean temperature occupied (2-way ANOVA; for ration, $F_{3,42}=7.01, \mathrm{p}=0.001$; for stratification type, $F_{1,42}=41.87, \mathrm{p}<0.001$; for interaction, $F_{3,42}=0.43, \mathrm{p}=$ 0.729). Sablefish held on the lowest ration level (no food for $60 \mathrm{~d}$ ) occupied significantly lower temperatures than fish on the other 3 rations, which did not differ from each other (post-hoc Tukey tests, $\alpha=0.05$ ). The average temperature occupied by fish on the lowest ration during non-resting observations was $3.2^{\circ} \mathrm{C}$ colder than that occupied by fish held on ad libitum rations in the respective stratification regimes.

Activity levels, indexed by mean swimming speeds during non-resting observations, were significantly influenced by ration level but not the type of thermal stratification (Fig. 7 ; 2 -way ANOVA; for ration, $F_{3,42}=$ $5.28, \mathrm{p}=0.004$; for stratification type, $F_{1,42}=1.34, \mathrm{p}=$ 0.254 ; for interaction, $\left.F_{3,42}=0.27, \mathrm{p}=0.844\right)$. Swimming activity for sablefish in the lowest ration treatment was significantly lower than at the 2 highest ration levels, but there were no other significant differences (post-hoc Tukey tests, $\alpha=0.05$ ).

\section{Natural sea surface temperature patterns}

To provide an estimate of the temperature extremes age-0 sablefish would encounter under natural conditions, we examined surface temperatures near the southern end of their larval/juvenile distribution

Table 4. Mean $( \pm \mathrm{SE})$ percentage of time spent resting on the bottom for juvenile sablefish in the behavior experiments. Fish were observed in isothermal $\left(12^{\circ} \mathrm{C}\right)$, warm $\left(19^{\circ} \mathrm{C}\right.$ at surface, $11^{\circ} \mathrm{C}$ at bottom), or cold $\left(14^{\circ} \mathrm{C}\right.$ at surface, $6^{\circ} \mathrm{C}$ at bottom $)$ stratified temperature regimes and held on ration levels of high, maintenance, no food for $30 \mathrm{~d}$, or no food for $60 \mathrm{~d}$ prior to observations

\begin{tabular}{|lcccc|}
\hline Thermal regime & High & Maintenance & Ration & Zero-30 \\
\hline Isothermal & $15.6(10.7)$ & & & Zero-60 \\
Warm stratified & $4.5(4.5)$ & $12.5(1.3)$ & $19.7(9.7)$ & $49.0(7.1)$ \\
Cold stratified & $0.0(0.0)$ & $10.4(10.4)$ & $29.2(12.3)$ & $40.2(12.2)$ \\
\hline
\end{tabular}



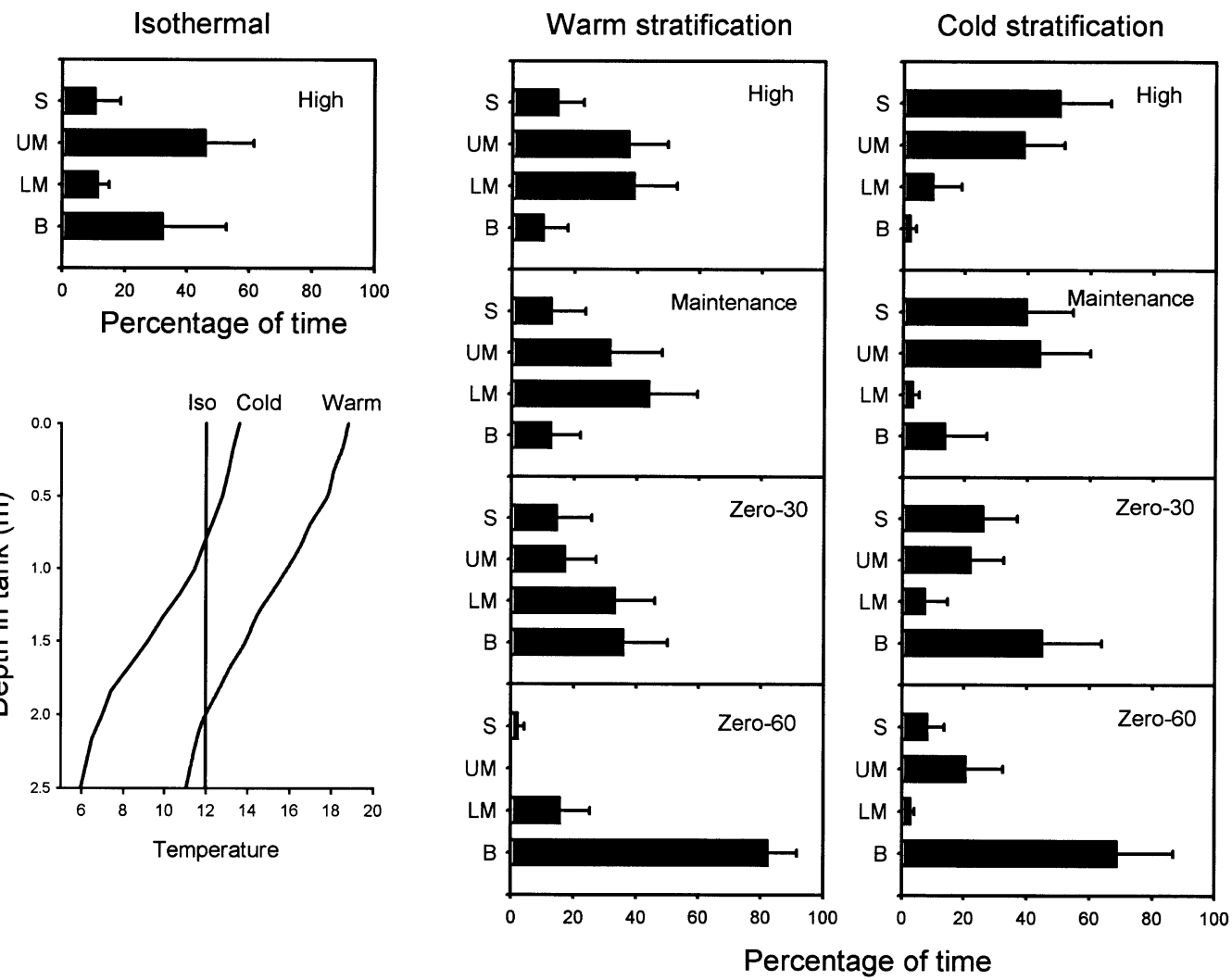

Fig. 6. Mean $( \pm \mathrm{SE})$ percentage of time spent by juvenile sablefish in each of 4 depth strata $(\mathrm{S}=$ surface, $\mathrm{UM}=\mathrm{upper}$ middle, $\mathrm{LM}=$ lower middle, $\mathrm{B}=$ bottom $)$ in $2.5 \mathrm{~m}$ tall tanks with isothermal $\left(12^{\circ} \mathrm{C}\right)$, warm $\left(19^{\circ} \mathrm{C}\right.$ at surface, $11^{\circ} \mathrm{C}$ at bottom), or cold $\left(14^{\circ} \mathrm{C}\right.$ at surface, $6^{\circ} \mathrm{C}$ at bottom) stratified temperature regimes. Fish were held on ration levels of high (ad libitum), maintenance ( $2 \%$ body weight $\mathrm{d}^{-1}$ ), no food for $30 \mathrm{~d}$, or no food for $60 \mathrm{~d}$ prior to observations. Graph at lower left displays thermal regime for each stratification treatment

range. The Integrated Global Ocean Services System (IGOSS, http://ingrid.ldgo.columbia.edu/SOURCES/ IGOSS) provides mean monthly sea surface temperatures from 1982 to the present in $1^{\circ}$ grids of latitude and longitude. Based on neuston collections reported by Moser et al. (1994), sablefish larvae are rare south of about $40^{\circ} \mathrm{N}$. We examined temperatures at $128.5^{\circ} \mathrm{W}$, $40.5^{\circ} \mathrm{N}$ to determine extremes at a location within Moser et al.'s sampling area but near the southern limit of abundance and outside the primary influence of inshore coastal upwelling. At this location, monthly means did not exceed $19^{\circ} \mathrm{C}$ during the last $19 \mathrm{yr}$ (Fig. 8). The extreme surface warming associated with the 1997 El Niño was clearly evident. Although larval sablefish are extremely rare south of northern California (Moser et al. 1994), migration and physical processes can transport juveniles to remote locations. Age-0 juveniles associated with drifting kelp were collected off Baja California at $115.5^{\circ} \mathrm{W}, 28.5^{\circ} \mathrm{N}$ by Mitchell \& Hunter (1970). At this location temperatures exceeded $22^{\circ} \mathrm{C}$ during 5 of the last $19 \mathrm{yr}$ and averaged $24.4^{\circ} \mathrm{C}$ in September 1997.

\section{DISCUSSION}

The sablefish tested in our experiments belong to the west coast population, whose adults range from southwest Vancouver Island to Baja California (Kimura et al. 1998). For this population, age-0 fish appear to be capable of tolerating and continuing to thrive at temperatures exceeding those likely to be encountered naturally. Even under the most extreme scenarios of elevated temperatures associated with El Niño events or global warming, temperatures in the primary nursery waters for this population are not likely to exceed the $22^{\circ} \mathrm{C}$ limit for favorable growth conditions suggested by our results. However, adult populations off southern California and Baja California appear to depend on recruitment of pelagic juveniles from further north, since the absence of eggs and larvae in this area suggests either minimal spawning or extremely high initial mortality (Moser et al. 1994). Sea surface temperatures are increasingly likely to exceed those allowing positive growth as juveniles migrate further south or further offshore of upwelling zones, and may 

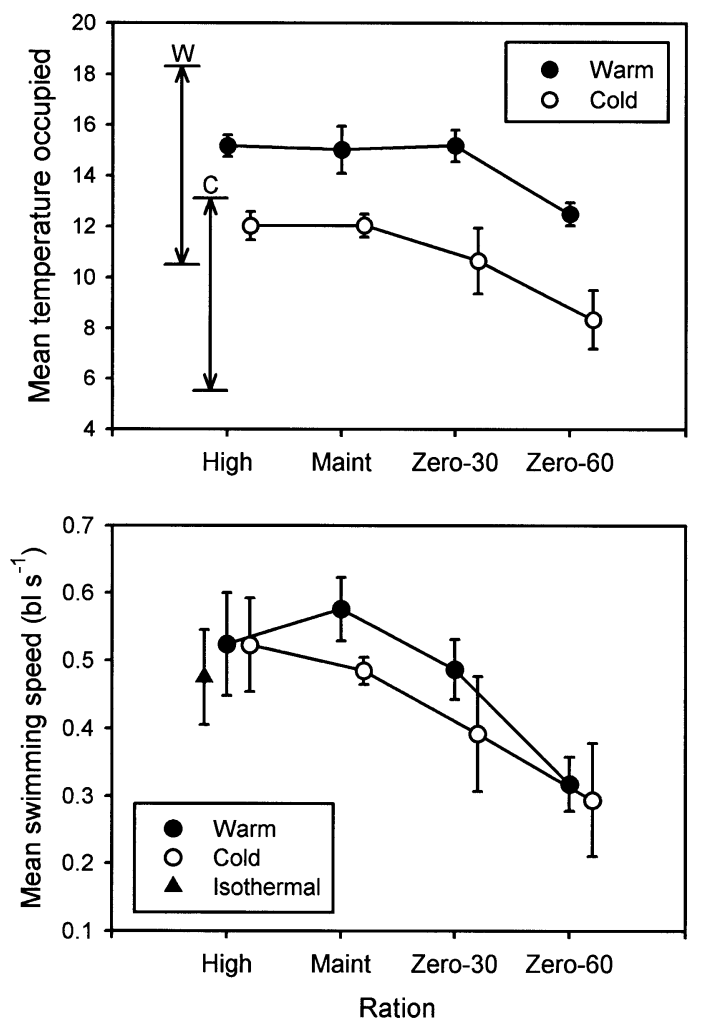

Fig. 7. Mean ( \pm SE) temperature occupied (upper graph) and swimming speed in body lengths $\mathrm{s}^{-1}$ (lower graph) for juvenile sablefish in either a warm $\left(19^{\circ} \mathrm{C}\right.$ at surface, $11^{\circ} \mathrm{C}$ at bottom), or cold $\left(14^{\circ} \mathrm{C}\right.$ at surface, $6^{\circ} \mathrm{C}$ at bottom) vertically stratified water column. Only non-resting observations, with fish actively swimming in the water column, were included in calculations. Fish were held on ration levels of high (ad libitum), maintenance $\left(2 \%\right.$ body weight $\left.d^{-1}\right)$, no food for $30 \mathrm{~d}$, or no food for $60 \mathrm{~d}$ prior to observations. Arrows display the range of temperatures available to the fish under warm (W) or cold

(C) stratification regimes

be a contributing factor in the sporadic success of year classes in southern California. The implication of our experimental results in conjunction with sea surface temperature data is that direct effects of elevated temperatures will impact neustonic juveniles only at the extreme southern end of the species' range. El Niño events are predicted to occur with increased frequency as a consequence of global warming (Timmermann et al. 1999), and in conjunction the 2 climatic processes will presumably further restrict the likelihood of favorable temperatures in southern habitats. For the overwhelming majority of the population, however, impacts of warming processes will likely be manifested in indirect rather than direct effects.

This conclusion should be considered in light of some cautionary notes. First, the demarcation between highly favorable and highly unfavorable temperatures for growth and survival in juvenile sablefish is ex- tremely sharp. For other species, the decline in growth with increasing temperature appears to be more gradual, with the growth/temperature relationship conforming to a general parabola around the optimal temperature for growth (Brett et al. 1969, Woiwode \& Adelman 1991, Björnsson \& Tryggvadóttir 1996, but see Thyrel et al. 1999). Our results for juvenile sablefish, in contrast, suggest a gradual rise or plateau in growth rates from 14 to $22^{\circ} \mathrm{C}$, then a severe decline at higher temperatures. Should temperatures exceed the upper breakpoint even for short time periods, growth and survival of juvenile sablefish would presumably be severely compromised. Species with more parabolic patterns of growth with temperature increase may more readily endure short periods of elevated temperatures.

Another precaution in interpreting our results relates to any long-term effects of exposure to elevated temperatures. Our experiments were short in duration, with fish experiencing target temperatures for only 2 wk. We do not know the physiological consequences of longer exposure times. For example, in the $24^{\circ} \mathrm{C}$ treatment, fish were able to survive and exhibit positive growth during the first week, but mortality averaged $73 \%$ by the end of the second week. Tolerance for elevated temperatures by juvenile sablefish likely decreases with increasing fish size. Many fish species display an ontogenetic shift downward in the optimal temperature for growth (e.g., Björnsson \& Tryggvadóttir 1996, Imsland et al. 1996, McCarthy et al. 1998). The higher mortality in the growth experiment for the second trial at $24^{\circ} \mathrm{C}$, when fish were larger than in the first trial, implies a similar trend for sablefish. At the

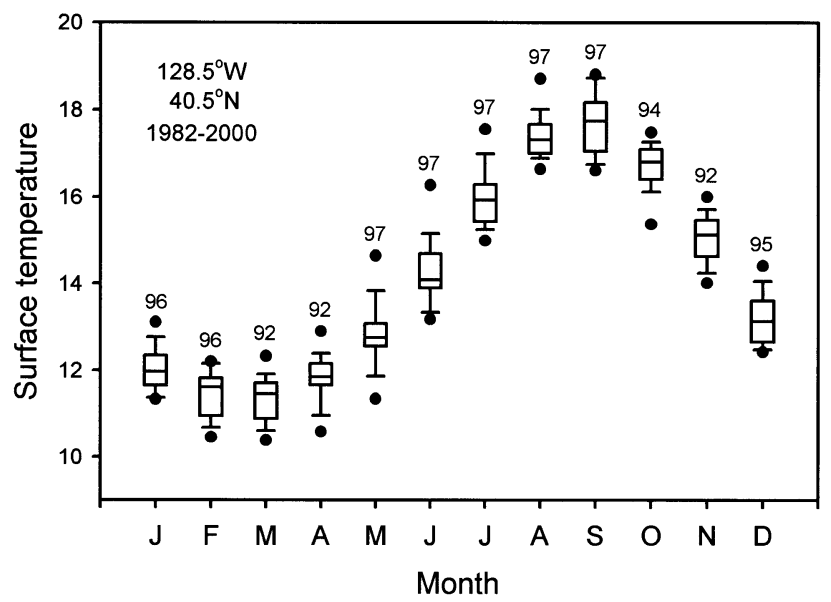

Fig. 8. Box plots denoting median, 25th and 75th percentiles (box), 10th and 90th percentiles (error bars), and ranges (symbols) for mean monthly sea surface temperatures at $128.5^{\circ} \mathrm{W}$, $40.5^{\circ} \mathrm{N}$ for 1982 to 2000 . Data were derived from the Integrated Global Ocean Services System. The year of the highest temperature for each month is noted 
end of the first summer, sablefish begin migrating to demersal shelf/slope habitats and much colder temperatures, and likely have a reduced capacity for growth at high temperatures.

The elevated temperatures in our experiments produced some of the fastest growth rates recorded for juvenile teleost fishes. To our knowledge, only tropical pelagic species such as mackerels, tunas, billfishes, and dolphin have exhibited growth rates exceeding $3 \mathrm{~mm} \mathrm{~d}^{-1}$ (Oxenford \& Hunte 1983, Prince et al. 1991, Peters \& Schmidt 1997). Growth rates of juvenile bluefish Pomatomus saltatrix, a temperate, epipelagic species, approached those demonstrated by similar sized sablefish, but at warmer temperatures of 21 to $30^{\circ} \mathrm{C}$ (Juanes \& Conover 1994, Buckel et al. 1995). We do not know the consequences of continued growth at faster than normal rates. Evidence of less than maximal growth rates in numerous species suggests that there are costs associated with rapid growth, including reduced allocation to repair and maintenance functions, impaired developmental capacity, and increased risk of predation (Arendt 1997). Fish occurring in elevated temperatures and growing at accelerated rates may be sacrificing other ecological requirements that will eventually have a detrimental influence on their survival. In addition, fish in our experiments were subjected to relatively benign conditions, in the absence of environmental stresses that may have interacted with elevated temperatures to depress growth, e.g., avoidance of predators and potential disease challenges. Only limited information is available on natural growth rates; otolith increments of field collected juveniles (100 to $260 \mathrm{~mm}$ ) yielded estimates of growth rates $<2 \mathrm{~mm} \mathrm{~d}^{-1}$ (Boehlert \& Yoklavich 1985), but these estimates are based on a small sample that may have been biased due to gear avoidance by larger, faster growing juveniles.

Oceanographic processes in northeast Pacific ecosystems are driven by 2 fluctuating climate regimes, which appear to have a major influence on recruitment of marine fishes (Hollowed \& Wooster 1992, Beamish et al. 1999). King et al. (2000) examined long-term recruitment patterns of sablefish off British Columbia and found an association of strong year classes with the warm or type B regime. Along the west coast, this regime is characterized by intense Aleutian Lows in winter, a higher frequency of winds from the southwest, and warmer nearshore sea surface temperatures compared to the cold regime. Although King et al. (2000) suggest that the causal mechanism underlying this pattern is related to copepod productivity during the early larval stage, faster growth in conjunction with warmer temperatures during the juvenile stage is also a plausible mechanism for enhanced survival of early life stages, assuming mortality has a size- dependent component. Our results are consistent with a pattern of enhanced growth during warmer climate regimes, as long as sufficient food is available.

Patterns of conversion efficiency in juvenile sablefish followed our predictions, with the optimal temperature for conversion decreasing as ration was reduced. This result is consistent with the general teleost pattern of increased metabolic rates with increased temperature and a proportionately higher energy requirement for maintenance functions. Efficiency declined for both rations at the highest temperature tested, $22^{\circ} \mathrm{C}$. The results of the efficiency experiment, however, were not fully consistent with the results of the growth experiments. First, at low ration levels, efficiency declined as temperature increased, but growth rates were comparable from 10 to $22^{\circ} \mathrm{C}$ in both experiments. The overall reduction in growth on restricted rations may not have allowed distinction of small differences in growth rate among temperatures. Second, at high ration levels in the efficiency experiment, efficiency declined at $22^{\circ} \mathrm{C}$, suggesting that growth rates should also decline at this temperature. Such a decline was observed in the efficiency experiment, but in the growth experiment the fastest growth occurred at $22^{\circ} \mathrm{C}$. Because specific growth rates were closely similar between the 2 experiments at other temperatures, the discrepancy was not likely due to the experimental setups. Actual temperatures for the $22^{\circ} \mathrm{C}$ treatment varied slightly between the growth and efficiency experiments, with averages of 21.8 and $22.0^{\circ} \mathrm{C}$, respectively. In addition, the initial size of fish at $22^{\circ} \mathrm{C}$ was larger in the efficiency experiment (mean $=64 \mathrm{~mm}$ ) than in the growth experiments (50 $\mathrm{mm})$. We make note of the contrast in growth rates to emphasize that a decline in consumption and/or conversion efficiency at $22^{\circ} \mathrm{C}$ may not have occurred in the growth experiment. The contrast also reiterates the tenuous nature of the breakpoint between favorable and unfavorable temperatures for juvenile sablefish.

It is difficult to compare conversion efficiency across species due to differences in methods and diet composition. Methods using wet weight values are imprecise as the percentage moisture of either the food or the fish that consumes it are unknown. Efficiencies based on dry weights are more informative, but often data on diet composition are lacking. For species that have been analyzed using dry weight estimates, sablefish have moderate rates of conversion. The overall average efficiency was $27.8 \%$, and the average for the most efficient treatment (high ration and $20^{\circ} \mathrm{C}$ ) was $34.2 \%$. In contrast, favorable foraging conditions have produced dry weight or energy $(\mathrm{kJ})$ conversion rates of $37 \%$ in juvenile plaice Pleuronectes platessa (Edwards et al. 1969), $47 \%$ in juvenile hogchokers Trinectes maculatus (Peters \& Boyd 1972), $45 \%$ in juvenile halibut Hippoglossus hippoglossus (Björnsson \& Tryggva- 
dóttir 1996), $52 \%$ in juvenile rainbow trout Oncorhynchus mykiss (Dockray et al. 1998), and 63\% in juvenile Arctic charr Salvelinus alpinus (Lyytikäinen \& Jobling 1999). These comparisons suggest that the high growth rates exhibited by sablefish are not driven by particularly high rates of conversion. Instead, we believe the rapid growth rates must be driven by high consumption rates. On a dry weight basis, sablefish on ad libitum rations at favorable temperatures (16 and $20^{\circ} \mathrm{C}$ ) averaged a $40 \%$ daily consumption rate. These prey requirements further emphasize that accelerated growth at elevated temperatures is possible only with sufficient prey quantity and quality. Our calculated rates of consumption and conversion efficiency in juvenile sablefish closely match those measured for juvenile bluefish, which had consumption rates up to $36 \%$ and efficiencies up to $30 \%$ (both as dry weight) depending on the type of prey offered (Juanes \& Conover 1994).

Proximate composition (percentage dry weight) was a clear function of growth rate and not significantly influenced by temperature. Comparable associations of reduced water content with faster growth rates have also been observed in other species (Miglavs \& Jobling 1989, Ali et al. 1998, Dockray et al. 1998). Because dry weight is generally correlated with lipid content in proximate composition analyses (Brett et al. 1969, Weatherly \& Gill 1983, Jonsson \& Jonsson 1998, Lyytikäinen \& Jobling 1999), the implication is that fish growing at faster rates allocate proportionately more energy to lipid storage. Conversely, fish experiencing poor foraging conditions may preferentially allocate energy to growth, ensuring an increase in size and a reduction in vulnerability to size-dependent mortality processes while sacrificing energy storage. Evidence for such a strategy has been observed in juvenile silversides Menidia menidia by Schultz \& Conover (1997). The only known field data on proximate composition of juvenile sablefish reported a mean of $16.9 \%$ dry weight for 3 fish (55 to $69 \mathrm{~mm}$ ) captured by tufted puffins (Van Pelt et al. 1997). This value is at the low end of the range we found in laboratory-acclimated fish, suggesting suboptimal foraging and growth conditions. Our laboratory experiments provided an exceptionally high quality food obtainable with minimal effort by foraging sablefish; in the field such propitious foraging conditions may be rare. A clear influence of prey quality on sablefish growth was documented by Shenker \& Olla (1986), with much faster growth obtained with a diet of mysid shrimp compared to a diet of adult Artemia spp.

Temperature and ration level significantly influenced vertical distribution in the behavior experiments. The contrast in distribution patterns observed for the 2 types of stratification regimes (cold and warm) indicated that the response was related to temperature and not simply to a preferred depth in the water column. Under high rations, fish in the cold stratification regime clearly avoided cold, deep layers by remaining in the upper half of the water column, in contrast to fish on high rations in the warm regime, which appeared to avoid the warm surface layer and occurred primarily in the middle range of available temperatures. As rations declined, fish in the warm regime demonstrated increasing avoidance of the warmer layers in the upper half of the water column, but the response by fish in the cold regime was not as severe. Temperatures occupied by fish on high rations in the warm regime averaged about $15^{\circ} \mathrm{C}$, which was $3^{\circ} \mathrm{C}$ warmer than their acclimation temperature and within the plateau range of temperatures supporting the fastest growth rates (Fig. 2). Thus, well-fed fish actively selected elevated temperatures, but not the warmest available, which would have provided comparable or slightly higher growth and efficiency benefits. In the cold regime, fish on high rations occurred primarily in the warmest layers available, averaging about $12^{\circ} \mathrm{C}$.

With reduced rations, sablefish increased their utilization of colder temperatures both by increased resting behavior and by reduced occurrence in upper water layers during active swimming periods. This energy conserving response to food deprivation was markedly similar to that observed for juvenile walleye pollock Theragra chalcogramma in comparable experiments (Sogard \& Olla 1996). The extent to which age-0 sablefish might move into deeper, colder water layers in the sea as foraging success declines is unknown. As larvae and early juveniles, they appear to be obligate neuston residents (Doyle et al. 1994). Our prior laboratory experiments have also suggested that smaller juveniles are less likely to move downward in either an isothermal or stratified water column, although reduced rations increase downward movement even for small juveniles (Sogard \& Olla 1998a). In the present study, the vertical distribution experiments used larger age-0 juveniles (232 to $365 \mathrm{~mm}$ ) that were near the sizes first observed in nearshore bottom waters. Similar experiments will be needed to determine if smaller size classes also exhibit a bioenergetic response to food deprivation.

Activity levels, as indexed by resting behavior and mean swimming speeds during non-resting periods, were markedly impacted by ration level. Decreased activity levels and increased time spent resting as ration declined could also serve as energy-conserving mechanisms when foraging success diminishes. Similar responses have been observed in juvenile walleye pollock (Sogard \& Olla 1996) and Atlantic cod (Björnsson 1993), although in the those species activity levels were highest at intermediate rations, presumably asso- 
ciated with increased searching behavior. We did not measure metabolic rates, but the clear reductions in activity and temperatures occupied by fish at the lowest rations level in either stratification regime suggest a substantial reduction in energy costs.

In conclusion, temperature increases of a few degrees can potentially enhance growth rates of neustonic juvenile sablefish, as long as sufficient food resources are available. However, the behavior of the fish under conditions of food deprivation suggests a clear motivation to reduce body temperature and conserve energy when foraging success declines. The high consumption rates, rapid growth rates and high activity levels of fish on ad libitum rations imply a costly lifestyle requiring high prey abundances. Within the majority of the species' range, the indirect effects of El Niño/La Niña cycles, oceanographic regime shifts, global warming or other climate change scenarios on transport processes, primary production, and consequent prey abundances are more likely to impact juvenile sablefish populations than the direct effects of elevated temperatures.

Acknowledgements. We thank Mara Spencer, Michele Ottmar, Erick Sturm, and Rich Titgen for their invaluable assistance in conducting experiments and analyzing videotapes.

\section{LITERATURE CITED}

Ali M, Przybylski M, Wootton RJ (1998) Do random fluctuations in daily ration affect the growth rate of juvenile three-spined sticklebacks? J Fish Biol 52:223-229

Arendt JD (1997) Adaptive intrinsic growth rates: an integration across taxa. Q Rev Biol 72:149-177

Bakun A (1996) Patterns in the ocean. California Sea Grant System, La Paz

Beamish RJ, Noakes DJ, McFarlane GA, Klyashtorin L, Ivanov VV, Kurashov V (1999) The regime concept and natural trends in the production of Pacific salmon. Can J Fish Aquat Sci 56:516-526

Björnsson B (1993) Swimming speed and swimming metabolism of Atlantic cod (Gadus morhua) in relation to available food: a laboratory study. Can J Fish Aquat Sci 50: 2542-2551

Björnsson B, Tryggvadóttir SV (1996) Effects of size on optimal temperature for growth and growth efficiency of immature Atlantic halibut (Hippoglossus hippoglossus L.). Aquaculture 142:33-42

Boehlert GW, Yoklavich MM (1985) Larval and juvenile growth of sablefish, Anoplopoma fimbria, as determined from otolith increments. Fish Bull 83:475-481

Brett JR, Shelbourn JE, Shoop CT (1969) Growth rate and body composition of fingerling sockeye salmon, Oncorhynchus nerka, in relation to temperature and ration size. J Fish Res Board Can 26:2363-2394

Buckel JA, Steinberg ND, Conover DO (1995) Effects of temperature, salinity, and fish size on growth and consumption of juvenile bluefish. J Fish Biol 47:696-706

Crowder LB, Magnuson JJ (1983) Cost-benefit analysis of temperature and food resource use: a synthesis with examples from the fishes. In: Aspey WP, Lustick SI (eds) Behavioral energetics: the cost of survival in vertebrates. Ohio State University Press, Columbus, p 189-221

Dockray JJ, Morgan IJ, Reid SD, Wood CM (1998) Responses of juvenile rainbow trout, under food limitation, to chronic low $\mathrm{pH}$ and elevated summer temperatures, alone and in combination. J Fish Biol 52:62-82

Doyle MJ, Rugen WC, Brodeur RD (1994) Neustonic ichthyoplankton in the western Gulf of Alaska during spring. Fish Bull 93:231-253

Edwards RRC, Finlayson DM, Steele JH (1969) The ecology of 0 -group plaice and common dabs in Loch Ewe. II. Experimental studies of metabolism. J Exp Mar Biol Ecol 3:1-17

Francis RC, Hare SR, Hollowed AB, Wooster WS (1998) Effects of interdecadal climate variability on the oceanic ecosystems of the NE Pacific. Fish Oceanogr 7:1-21

Grover JJ, Olla BL (1987) Effects of an El Niño event on the food habits of larval sablefish, Anoplopoma fimbria, off Oregon and Washington. Fish Bull 85:71-79

Hollowed AB, Wooster WS (1992) Variability of winter ocean conditions and strong year classes of Northeast Pacific groundfish. ICES Mar Sci Symp 195:433-444

Imsland AK, Sunde LM, Folkvord A, Stefansson SO (1996) The interaction of temperature and fish size on growth of juvenile turbot. J Fish Biol 49:926-940

Jobling M (1996) Temperature and growth: modulation of growth rate via temperature change. In: Wood CM, McDonald DG (eds) Global warming: implications for freshwater and marine fish. Cambridge University Press, London, p 225-253

Jonsson N, Jonsson B (1998) Body composition and energy allocation in life-history stages of brown trout. J Fish Biol 53:1306-1316

Juanes F, Conover DO (1994) Rapid growth, high feeding rates, and early piscivory in young-of-the-year bluefish (Pomatomus saltatrix). Can J Fish Aquat Sci 51:1752-1761

Kendall AW Jr, Matarese AC (1987) Biology of eggs, larvae, and epipelagic juveniles of sablefish, Anoplopoma fimbria, in relation to their potential use in management. Mar Fish Rev 49:1-13

Kimura DK, Shimada AM, Shaw FR (1998) Stock structure and movement of tagged sablefish, Anoplopoma fimbria, in offshore northeast Pacific water and the effects of El Niño-Southern Oscillation on migration and growth. Fish Bull 96:462-481

King JR, McFarlane GA, Beamish RJ (2000) Decadal-scale patterns in the relative year class success of sablefish (Anoplopoma fimbria). Fish Oceanogr 9:62-70

Lyytikäinen T, Jobling M (1999) Effects of thermal regime on energy and nitrogen budgets of an early juvenile Arctic charr, Salvelinus alpinus, from Lake Inari. Environ Biol Fish 54:219-227

Mac MJ (1985) Effects of ration size on preferred temperature of lake charr. Environ Biol Fish 14:227-231

McCarthy ID, Moksness E, Pavlov DA (1998) The effects of temperature on growth rate and growth efficiency of juvenile common wolffish. Aquacult Int 6:207-218

McFarlane GA, Beamish RJ (1992) Climatic influence linking copepod production with strong year-classes in sablefish, Anoplopoma fimbria. Can J Fish Aquat Sci 49:743-753

Miglavs I, Jobling M (1989) The effects of feeding regime on proximate body composition and patterns of energy deposition in juvenile Arctic charr, Salvelinus alpinus. J Fish Biol 35:1-11

Mitchell CT, Hunter JR (1970) Fishes associated with drifting kelp, Macrocystis pyrifera, off the coast of southern Cali- 
fornia and northern Baja California. Calif Fish Game 56: 288-297

Morgan MJ (1993) Ration level and temperature preference of American plaice. Mar Behav Physiol 24:117-122

Moser HG, Charter RL, Smith PE, Lo NCH, Ambrose DA, Meyer CA, Sandknop EM, Watson W (1994) Early life history of sablefish, Anoplopoma fimbria, off Washington, Oregon, and California, with application to biomass estimation. CALCOFI Rep 35:144-159

Oxenford HA, Hunte W (1983) Age and growth of dolphin (Coryphaena hippurus) determined by growth rings in otoliths. Fish Bull 84:906-909

Peters DS, Boyd MT (1972) The effect of temperature, salinity, and availability of food on the feeding and growth of the hogchoker, Trinectes maculatus (Block \& Schneider). J Exp Mar Biol Ecol 7:201-207

Peters JS, Schmidt DJ (1997) Daily age and growth of larval and early juvenile Spanish mackerel, Scomberomorus maculatus, from the South Atlantic Bight. Fish Bull 95: $530-539$

Prince ED, Lee DW, Zweifel JR, Brothers EB (1991) Estimating age and growth of young Atlantic blue marlin Makaira nigricans from otolith microstructure. Fish Bull 89:441-459

Rudstam LG, Magnuson JJ (1985) Predicting the vertical distribution of fish populations: analysis of cisco, Coregonus artedii, and yellow perch, Perca flavescens. Can J Fish Aquat Sci 42:1178-1188

Schultz ET, Conover DO (1997) Latitudinal differences in somatic energy storage: adaptive responses to seasonality in an estuarine fish (Atherinidae: Menidia menidia). Oecologia 109:516-529

Shenker JM (1988) Oceanographic associations of neustonic larval and juvenile fishes and dungeness crab megalopae off Oregon. Fish Bull 86:299-317

Shenker JM, Olla BL (1986) Laboratory feeding and growth of juvenile sablefish, Anoplopoma fimbria. Can J Fish Aquat Sci 43:930-937

Smith RL, Huyer A, Kosro PM, Barth JA (1999) Observations of El Niño off Oregon: July 1997 to present (October 1998). PICES Sci Rep 10:33-37

Sogard SM, Olla BL (1996) Food deprivation affects vertical distribution and activity of a marine fish in a thermal gradient: potential energy-conserving mechanisms. Mar Ecol Prog Ser 133:43-55

Editorial responsibility: Kenneth L. Heck Jr (Contributing Editor), Dauphin Island, Alabama, USA
Sogard SM, Olla BL (1998a) Behavior of juvenile sablefish, Anoplopoma fimbria (Pallas), in a thermal gradient: balancing food and temperature requirements. J Exp Mar Biol Ecol 222:43-58

Sogard SM, Olla BL (1998b) Contrasting behavioral responses to cold temperatures by two marine fish species during their pelagic juvenile interval. Environ Biol Fish 53: 405-412

Sogard SM, Olla BL (2000) Effects of group membership and size distribution within a group on growth rates of juvenile sablefish Anoplopoma fimbria. Environ Biol Fish 59: 199-209

Stuntz WE, Magnuson JJ (1976) Daily ration, temperature selection, and activity of bluegill. In: Esch GW, McFarlane RW (eds) Thermal ecology II. ERDA Symposium Series CONF-750425. Technical Information Service, Springfield, VA, p 180-184

Thyrel M, Berglund I, Larsson S, Näslund I (1999) Upper thermal limits for feeding and growth of 0+ Arctic charr. J Fish Biol 55:199-210

Timmermann A, Oberhuber J, Bacher A, Esch M, Latif M, Roeckner E (1999) Increased El Niño frequency in a climate model forced by future greenhouse warming. Nature 398:694-697

Van Pelt TI, Piatt JF, Lance BK, Roby DD (1997) Proximate composition and energy density of some North Pacific forage fishes. Comp Biochem Physiol 118A:1393-1398

Watson RT, Zinyowera MC, Moss RH, Dokken DJ (1997) The regional impacts of climate change: an assessment of vulnerability. Intergovernmental Panel on Climate Change, Cambridge University Press, Cambridge

Weatherley AH, Gill HS (1983) Protein, lipid, water and caloric contents of immature rainbow trout, Salmo gairdneri Richardson, growing at different rates. J Fish Biol 23: 653-673

Welch DW, Ishida Y, Nagasawa K (1998) Thermal limits and ocean migrations of sockeye salmon (Oncorhynchus nerka): long-term consequences of global warming. Can J Fish Aquat Sci 55:937-948

Woiwode JG, Adelman IR (1991) Effect of temperature, photoperiod, and ration size on growth of hybrid striped bass $\times$ white bass. Trans Am Fish Soc 120:217-229

Wooster WS, Fluharty DL (1985) El Niño North. Washington Sea Grant, Seattle

Submitted: November 7, 2000; Accepted: April 16, 2001

Proofs received from author(s): July 12, 2001 